\title{
Methane emissions are lower from reindeer fed lichens compared to a concentrate feed
}

\author{
Kia Krarup Hansen ${ }^{\mathrm{a}, \mathrm{b}}$, Monica Alterskjær Sundset ${ }^{\mathrm{a}}$, Lars P. Folkow ${ }^{\mathrm{a}}$, Marte Nilsen ${ }^{\mathrm{a}}$ \& Svein D. Mathiesen ${ }^{\mathrm{c}, \mathrm{d}, \mathrm{e}}$ \\ ${ }^{a}$ Department of Arctic and Marine Biology, UiT-The Arctic University of Norway, Tromsø, Norway; ${ }^{b}$ Department of Social Sciences, UiT \\ - The Arctic University of Norway, Tromsø, Norway; CUArctic EALAT Institute at International Centre for Reindeer Husbandry, \\ Kautokeino, Norway; dUiT-The Arctic University of Norway, Tromsø, Norway; eSaami University of Applied Science, Kautokeino, Norway
}

\begin{abstract}
Methane emissions from reindeer (Rangifer tarandus tarandus) fed lichens (mainly Cladonia stellaris) and a concentrate feed were determined using open-circuit respirometry. The lichen diet was low in crude protein $(<2.6 \%$ of dry matter [DM]), starch $(6.0 \% \mathrm{DM})$ and acid detergent lignin (2.0\% DM) compared to the concentrate feed $(12.7,22.5$ and $7.2 \%$ DM, respectively), and high in neutral detergent fibre (82.2\% DM versus $34.8 \% \mathrm{DM}$ in concentrate feed). The feeds were offered in equal amounts (ca. $0.440 \mathrm{~kg} \mathrm{DM}) 2 \mathrm{~h}$ after initiating methane recordings in the respiration chamber. The reindeer were adapted to these diets for $>4$ weeks prior to experiments and methane emissions recorded for two separate $23 \mathrm{~h}$ periods for each diet. Methane emissions increased on average by $0.93 \mathrm{~g} / \mathrm{h}$ (or by 5.8 times) in the first hour after feeding the concentrate feed, while emissions remained unchanged after the intake of lichens. Mean methane emissions from reindeer $(n=5)$ were $7.5 \pm 0.54$ (SE) g $\mathrm{CH}_{4}$ day $^{-1}$ when fed lichens, compared to a higher emission $(p=0.001)$ of $11.2 \pm 0.54 \mathrm{~g} \mathrm{CH}_{4}$ $\mathrm{day}^{-1}$ on the concentrate diet. The mean proportion of gross energy intake lost as methane was $5.2 \pm 0.37 \%$ on the lichens and $7.6 \pm 0.37 \%$, or some $50 \%$ higher, on the concentrate feed. This difference was significant $(p<0.001)$. Our results suggest that it is of environmental importance to preserve the lichens on the tundra and minimize supplementary feeding with concentrate diets, in order to reduce methane emission.
\end{abstract}

\section{KEYWORDS}

Respirometry; dietary secondary compounds; energy loss; Rangifer tarandus

\section{ABBREVIATIONS}

AIC: Akaike Information Criterion; DMl: dry matter intake; GEl: gross energy intake; RO: ruminantiumolleyae clade; SGMT: smithiigottschalkii-millerae-thaueri clade; STPD: standard temperature and pressure dry; UiT: UiT-The Arctic University of Norway

\section{Introduction}

Globally only about $40 \%$ of the total ice-free land area is suitable for land agriculture. A further expansion of crop and pasture land or an intensification of agriculture is undesirable because this will contribute to the loss of biodiversity, climate change, increased resource use and pollution. Dietary change and decreases in food waste are essential to reduce greenhouse gas emission and provide global food security by 2050 (Bajzelj et al. 2014). As much as $8 \%$ of the land surface is dominated by lichens, particularly in northern and alpine areas (Nash 1996). Lichens are well known for their high content of phenolic secondary compounds, synthesized as a defense against consumption by herbivores and UV-B radiation (Ingolfsdottir 2002). Reindeer (Rangifer tarandus), unlike most other ruminants, are able to utilize lichens as an important source of energy and nutrients in winter (Norberg et al. 2001; Storeheier, Mathiesen, Tyler \& Olsen 2002). About 2 million of the world population of reindeer are semidomesticated and herded between natural pastures year around, in a sustainable transhumant system by ethnic minorities in Russia and Fennoscandia (Turi 2002). Multiple drivers of environmental and social change can be identified in the reindeer herders' grazing land in the Barents region and more change is expected. Infrastructure development is currently the most significant driver of change in land use and climate change is an increasing threat to traditional livelihoods (Degteva et al. 2017).

As ruminants, reindeer rely on a symbiotic relationship with a diverse microflora of bacteria, ciliate protozoa, anaerobic fungi and methanogenic archaea in their anaerobic rumen and hindgut, to utilize plant cell wall carbohydrates (Sundset et al. 2007; Sundset et al. 2009a, 2009b). One of the end products of rumen microbial fermentation is methane $\left(\mathrm{CH}_{4}\right)$. Methanogenesis is undertaken by methanogenic archaea, which remove $\mathrm{H}_{2}$ from the fermentation to reduce $\mathrm{CO}_{2}$ and form $\mathrm{CH}_{4}$. Emitted methane represents a loss of energy to the host animal, and also contributes to the global greenhouse effect (Johnson \& Johnson 1995; Moss et al. 2000). Ways of modulating the rumen microbiota have been explored as an approach to mitigating methane emission and thereby curtail global warming (Eckard et al. 2010; Martin et al. 2010).

Several equations have been developed to predict $\mathrm{CH}_{4}$ production in ruminants using data generated 
by respiration chamber studies of cattle and sheep. The equations are based on DMI, level of feed intake and energy digestibility, digestible carbohydrates, or on a range of other dietary and animal factors (Kriss 1930; Blaxter \& Clapperton 1965; Moe \& Tyrrell 1979; Holter \& Young 1992). Analysing a data set including 289 means from 52 different studies, Ramin \& Huhtanen (2013) concluded that feed intake is the main determinant of total methane production. Furthermore, they showed that $\mathrm{CH}_{4}$ energy as a proportion of GEI is negatively related to feeding level and dietary fat concentration and positively related to diet digestibility. Dietary carbohydrate composition has only minor effects (Ramin \& Huhtanen 2013).

Even though huge amounts of data are available on methane emission from sheep and cattle, no data have been published on methane emission from reindeer to date, apart from a pilot study by Gotaas \& Tyler (1994). Numbers of rumen methanogens are generally lower in reindeer (Sundset et al. 2009b) compared to those found in, e.g., cattle (Denman et al. 2007; Evans et al. 2009; Hook et al. 2009). This might indicate lower methane emission from reindeer, as the density of methanogens in the rumen is directly proportional to the production of methane (Denman et al. 2007). The reindeer rumen microbiome is affected by a highly seasonal environment and forage chemistry. The amount of methane produced through rumen microbial digestion is therefore also expected to vary with season and diet. Little is known about the methanogenic archaea and what factors influence their diversity, density and methanogenesis in the reindeer rumen (Sundset et al. 2009a, 2009b). Consequently, the main objective of the present study was to measure and compare methane emission from reindeer on two different diets: one consisting of mixed lichen (mainly Cladonia stellaris), the other a commercial concentrate feed based on grain and grass. The diets were chosen because studies have shown that lichens may account for up to $50 \%$ of the winter diet of reindeer in some areas (Scotter 1967; Steen 1968; Gaare \& Skogland 1975; Boertje 1984). According to Inga (2007), Holleman \& Luick (1977) and Skogland (1975), reindeer prefer lichens of the genus Cladonia, while concentrate feeds are widely used as supplementary feed among herders in Fennoscandia (Tyler et al. 2007). The type used here (FK Reinfor) is the only one produced for reindeer in Norway (Josefsen \& Sundset 2014).

\section{Materials and methods}

\section{Animals}

Five female semi-domesticated reindeer $(1.5-2 \mathrm{yr}$ of age) were used in this experiment. The animals were formerly owned and herded by Saami reindeer herders. After collection from their herd in Tønsvika outside Tromsø in northern Norway $\left(69^{\circ} \mathrm{N}, 19^{\circ} \mathrm{E}\right)$, the animals were transported to the animal research facilities at the Department of Arctic and Marine Biology at UiT. On arrival, the reindeer were inspected by a veterinarian, given routine anti-parasite treatment $(10 \mathrm{ml}$ Ivomec Oract [Merial]) and tagged with numbered ear tags for identification. Between experiments and the feed habituation periods, the reindeer were kept outdoors, or in indoor pens under simulated photoperiod conditions corresponding to $69^{\circ} \mathrm{N}$, with ad libitum access to feed (pellets and/or lichens) and water unless otherwise stated. Their body mass was frequently measured and their surroundings cleaned daily. As experiments required that animals were handled and placed inside a respirometry chamber, preparatory training and habituation over many months was conducted. All experiments were carried out in winter, with animals in their full winter pelage.

\section{Respirometry measurements}

Enteric methane emission was measured in an opencircuit respiration chamber system consisting of an aluminium box $\left(1.3 \mathrm{~m}^{3}\right)$ with a transparent front. The box was placed inside a climatic chamber at a temperature of $0^{\circ} \mathrm{C}$ in order to secure thermoneutral conditions for the animals (Nilssen et al. 1984). The outlet air was pulled from a hole through the top of the respiration chamber via a tube that was connected to a negative pressure air pump that provided an airflow of $120-140 \mathrm{l} \cdot \mathrm{min}^{-1}$. Air flow was measured with a mass flow meter (type G-40, Elster A/G Mainz). The flowmeter was checked against a Singer DTM-325 volumeter that had been controlled by running known volumes of air from a mechanical spirometer through it. Small openings at the bottom rear wall of the chamber allowed fresh inlet air to enter. A fan circulated the air inside the box in order to secure that the respired air from the animal could not leave through the air inlet openings. The concentration of $\mathrm{CH}_{4}$ in both outlet and inlet air was determined using a Binos-100 methane analyser (Rosemount), to allow calculation of the methane production of the animal. Also, the concentration of $\mathrm{O}_{2}$ was continuously monitored with a 3-SA oxygen analyser (Applied Electrochemistry), mainly to assure that the box was always adequately ventilated. Gas temperature $\left(\mathrm{T}_{\text {gas }},{ }^{\circ} \mathrm{C}\right)$ and relative humidity (\%) of the outlet air were recorded using a thermo- and hygrometer (Vaisala HMI 32), for use in calculation of water vapour content for STPD corrections of gas flow. Gas subsamples were drawn from the main air flow tube and fed into a pressure reduction chamber via a small pump (Thomas Industries), and from 
there the gas analysers pulled gas via columns containing a drying agent (Calciumchlorid, Merck $\mathrm{KGaA}$ ) for removal of water vapour prior to analysis. Before each experiment, the methane analyser was calibrated using a certified AGA 99.99\% pure $\mathrm{N}_{2}$ as a zero (baseline), and 997 mol-ppm (0.0997\%) $\mathrm{CH}_{4}$ in $\mathrm{N}_{2}$ as a reference. The oxygen analyser was calibrated against $99.99 \%$ pure $\mathrm{N}_{2}$ and ambient air $\left(20.95 \% \mathrm{O}_{2}\right)$ before experiments and then checked manometrically at weekly intervals. Analogue signals from all instruments were digitized by an $\mathrm{A} / \mathrm{D}$ converter (PowerLab/16sp, ADInstruments), and then recorded as 30-s means on a computer using the programme Chart v5 for Windows (PowerLab, ADInstruments).

\section{Experimental procedures}

Methane emission experiments were carried out with all five reindeer, twice per animal per diet. Hence, a total of 10 individual recordings per diet were conducted. The diets were either a concentrate feed containing $23.0 \%$ oats, $18.9 \%$ timothy grass, $16.0 \%$ wheat bran, $11.2 \%$ barley, $7.8 \%$ beet pulp, $5.0 \%$ oat meal flour, $5.0 \%$ molasses, $0.8 \%$ soya extract, $1.5 \%$ vegetable fat and $10 \%$ premix including vitamins $\left(A, D_{3}, E\right.$, Copper, Selen) (FK Reinfor, Felleskjøpet, Norway) or mixed lichens (mainly Cladonia stellaris) picked in Østerdalen, in southern Norway. The lichens were kept frozen at $-20^{\circ} \mathrm{C}$ until use. To avoid problems with variable feed intake between individuals during experiments, we offered all animals a limited amount of ca. $0.440 \mathrm{~kg}$ DM feed during each experiment, to ensure that there were not feed refusals. The amount of feed was based on our experiences with food intake of the experimental animal during training. We also took into consideration that the feed intake of reindeer under natural conditions is much reduced in winter (Larsen et al. 1985). Prior to the experiments, the reindeer were given ad libitum access to the relevant feed in a four-week habituation period, to allow both the digestive tract and the gut microflora time to adapt to the feed. The last week before the measurements, the reindeer were given the same restricted amount of feed that was given during the experiment, thereby adapting the animals to the experimental feed rations. As a consequence, the animals lost some body mass during the course of the experiments (Table 2). The animals were kept inside approved animal indoor pens at the department during both the habituation and experimental periods. The water contents of the lichens and pellets were determined prior to the experiment, to allow calculation of the wet weight of feed that would correspond to $0.440 \mathrm{~kg}$ DM. The feed was kept in plastic bags at $-20^{\circ} \mathrm{C}$ until thawing, $2 \mathrm{~h}$ before feeding.
Pilot experiments showed an immediate response in methane emission to feeding pellets, while it took more than $12 \mathrm{~h}$ for methane emission to return to baseline levels (background levels before feed). In order to obtain the best possible estimate of the daily methane emission on each specific diet and daily ration, we aimed to conduct measurements over a full $24 \mathrm{~h}$ cycle. However, to allow repeating measurements, change of experimental animal and resetting of equipment, measurements were conducted for $23 \mathrm{~h}$, while the 24th h was extrapolated.

As stated above, methane emission was determined twice for each animal on each diet. To allow the animals to rest between experiments, these were not on consecutive days. One measurement with animal no. 10 on the lichen diet was excluded because outlet gas by mistake was not analysed during the first $3 \mathrm{~h}$ of that experiment. All experiments started at 09:10. Concentrations of $\mathrm{CH}_{4}$ and $\mathrm{O}_{2}$ of the outlet (animal) air were recorded for $50 \mathrm{~min}$ every hour, followed by 10 min recording of inlet air concentrations, to determine background gas levels. The average gas concentration was logged every $30 \mathrm{~s}$. The animals were fed $2 \mathrm{~h}$ into the experiment, to keep their normal routine, and to allow a 2-h recording of baseline methane levels prior to feeding. Water was not offered until about $6 \mathrm{~h}$ into the experiment, to avoid spillage of food due to mixing with water. Lights were on during all experiments to permit continuous surveillance of the animal via a video camera. Body mass was determined before and after each experiment.

\section{Calculations}

The mean hourly differences in gas concentrations ( $\triangle \mathrm{CH}_{4}$ and $\Delta \mathrm{O}_{2}$, in \%) between outlet and inlet air were determined based on 50 min of outlet air recording, and the $2 \times 10 \mathrm{~min}$ of inlet air recording before and after each outlet air recording. On shifting between sampling of outlet and inlet air, 2-5 $\mathrm{min}$ passed before the dead space gas in the system had been replaced. Therefore, only the last $45 \mathrm{~min}$ of the outlet air recording and the last $5 \mathrm{~min}$ of the two inlet air recordings were used for hourly gas concentration calculations. The hourly STPD-corrected volume of methane emitted $\left(V_{\mathrm{CH} 4}\left(1 \cdot \mathrm{h}^{-1}\right)\right)$ was calculated as follows:

$$
V_{C H 4}=\Delta \% \mathrm{CH}_{4} \times 0.01 \times 60 \times \text { Flow }_{S T P D}
$$

Flow $_{S T P D}\left(1 \cdot \mathrm{min}^{-1}\right)$ is the dry air flow at standard temperature $T_{s}(273.15 \mathrm{~K})$ and pressure $P_{s}(760 \mathrm{mmHg})$, as recorded with the mass flowmeter and then corrected by subtracting the vapour content of the gas. This was calculated based on the following equation (modified from Vaisala 2013): 


$$
\begin{aligned}
\text { Flow }_{S T P D} & =\text { Flow }_{S T P}-(\text { Flow } \times((R H / 100) \times 4.59 \\
& \left.\times\left(10^{\wedge}\left(\left(7.6 \times \mathrm{T}_{\text {gas }}\right) /\left(241+\mathrm{T}_{\mathrm{gas}}\right)\right)\right) / \mathrm{P}\right)
\end{aligned}
$$

$R H$ is relative humidity (\%), $T_{\text {gas }}$ is the gas temperature $\left({ }^{\circ} \mathrm{C}\right)$ and $P$ is air pressure $(\mathrm{mmHg})$. The hourly mean amount of methane emitted $\left(m_{\mathrm{CH}}\right.$; $\mathrm{g} \cdot \mathrm{h}^{-1}$ ) was calculated as follows:

$$
m_{\mathrm{CH} 4}=\left(\begin{array}{lll}
P_{s} \times V_{\mathrm{CH} 4} \times M_{\mathrm{CH} 4}
\end{array}\right) /\left(R \times T_{s}\right)
$$

$P_{s}, V_{C H 4}$ and $T_{s}$ are as defined above (for Eqn. 1), $M_{C H 4}$ is the molar mass of $\mathrm{CH}_{4}\left(16.043 \mathrm{~g} \cdot \mathrm{mole}^{-1}\right)$ and $\mathrm{R}$ is the gas constant $\left(62.36 \mathrm{l} \cdot \mathrm{mmHg} \cdot \mathrm{K}^{-1} \cdot\right.$ mole $\left.^{-1}\right)$.

Methane emission during the 24 th $\mathrm{h}$ that was not recorded was estimated as the mean of the emission during the first and the 23rd h. The total daily methane emission $\left(V_{\mathrm{CH} 4}\right.$, тOT $; 1 \cdot$ day $\left.^{-1}\right)$ on the experimental diets was then calculated by summing all hourly emission.

Gross energy lost as methane was determined by multiplying the total daily STPD-corrected methane emission $\left(V_{\mathrm{CH} 4}\right.$, тOT $; 1 \cdot$ day $\left.^{-1}\right)$ by the energy content of methane $\left(E C_{C H 4}=39.45 \mathrm{~kJ} \cdot \mathrm{l}^{-1}\right)$ (Brouwer 1965; Suzuki et al. 2007). Daily energy loss by methane emission $\left(E_{\mathrm{CH} 4}\right)$, as expressed in \% of daily GEI, is then:

$$
E_{\mathrm{CH} 4}=\left(\left(V_{\mathrm{CH} 4, \mathrm{TOT}} \times E_{\mathrm{CH} 4}\right) / G E I\right) \times 100
$$

GEI is equal to the product of the calorific value $\left(\mathrm{kJ} \cdot \mathrm{g}^{-1}\right)$ of the feed (Table 1 ) and the daily DM intake of the feed $\left(\mathrm{g} \cdot \mathrm{day}^{-1}\right)$, i.e., the ca. $0.440 \mathrm{~kg}$ of pellets or lichens that was offered to the reindeer each day.

Oxygen uptake rates $\left(V_{\mathrm{O} 2} ; \mathrm{l}_{\mathrm{O} 2} \mathrm{~kg}^{-1} \mathrm{day}^{-1}\right)$ were calculated in the same way as the methane emission rates, based on the STPD-corrected air flow and the difference in $\mathrm{O}_{2}$ concentration between inlet and outlet air and assuming an RQ of 1.

\section{Chemical analyses of the diet}

Prior to each experiment, subsamples from different locations of the feed-storage-container were collected, to obtain representative samples of the feed. The

Table 1. Chemical composition of the mixed lichen diet and the concentrate diet (mean \pm SD).

\begin{tabular}{lcc}
\hline & $\begin{array}{c}\text { Pellets } \\
(\mathrm{n}=2)\end{array}$ & $\begin{array}{c}\text { Lichens } \\
(\mathrm{n}=3)\end{array}$ \\
\hline Calorific equivalent (kJ. g-1 DM) & $18.5 \pm 0.05$ & $17.4 \pm 0.85$ \\
Dry matter (\%) & $88.9 \pm 0.10$ & $38.2 \pm 1.86$ \\
In \% of dry matter: & $12.7 \pm 0.10$ & $<2.6^{\mathrm{a}}$ \\
$\quad$ Crude protein & $4.7 \pm 0.16$ & $1.7 \pm 0.16$ \\
Fat & $7.8 \pm 0.10$ & $<2.6^{\mathrm{a}}$ \\
$\quad$ Ash & $5.9 \pm 0.05$ & $0.1 \pm 0.06$ \\
Water-soluble carbohydrates & $22.6(\mathrm{n}=1)$ & $6.0(\mathrm{n}=1)$ \\
Starch & $34.8 \pm 0.29$ & $82.2 \pm 1.13$ \\
$\quad$ Neutral detergent fibre & $1.9 \pm 0.01$ & $3.4 \pm 0.45$ \\
$\quad$ Acid detergent fibre & $7.2 \pm 0.21$ & $2.0 \pm 0.10$ \\
$\quad$ Acid detergent lignin & &
\end{tabular}

samples were stored at $-20^{\circ} \mathrm{C}$ for later analyses. The water content was determined by weighing each sample before drying (wet weight) and after drying, at first at $60^{\circ} \mathrm{C}$, then at $110^{\circ} \mathrm{C}$, until completely dry (dry weight). Samples were placed in previously dried beakers and stored in containers holding dried silica gel (ChemiTeknik AS) to prevent them from attracting moisture.

A mixture of the representative samples from each experiment (400 g pellets, $n=2$ and $300 \mathrm{~g}$ lichens, $n=3$ ) was used for the chemical analyses that were performed by Eurofins Food \& Agro Testing Norway AS.

The calorific values of the dry feeds were determined by use of an oxygen bomb calorimeter, type PARR 6300 (Thermo Fisher Scientific). The crude protein content was determined according to the Kjeldahl method (European Commission Directive $93 / 28 \mathrm{~m}$ ). To determine fat content, $5 \mathrm{~g}$ of the sample was covered with a fat-free wad of cotton wool, before extraction with light petroleum for $6 \mathrm{~h}$ in an extractor and oven-dried for $1.5 \mathrm{~h}$, followed by weighing. The ash content was determined by gradual heating of the weighed (5 g) samples until carbonization. Samples were then placed in a muffle-furnace at $550^{\circ} \mathrm{C}$ until the ash was white, light grey or reddish. Water-soluble carbohydrates were extracted with boiling water. The amounts of glucose and fructose were enzymatically determined after acid hydrolysis (Boehringer Mannheim 1984). The amount of starch was determined according to the Chatteris Laboratory of ASL Food and Pharmaceutical using their standard method $\mathrm{AM} / \mathrm{C} / 401$ based upon European Commission Regulation 152/2009. Starch content was corrected subtracting the aqueous alcohol extract reading (sugars) from the total optical rotation figure (starch plus sugars). The range of application is $0.1-100 \mathrm{~g} /$ $100 \mathrm{~g}$. DM was determined for the same samples and numbers are given in percent of DM (\% DM). Neutral detergent fibre content was determined in ground samples that were weighed before adding $100 \%$ neutral detergent solution and sodium sulphite prior to incubation for $16 \mathrm{~h}$ in a $90^{\circ} \mathrm{C}$ oven. Amylase was added $1 \mathrm{~h}$ before the end of incubation. After filtering through tarred crucibles with fitted discs and washing with water, the crucible was dried overnight and weighed. The neutral detergent fibre content was derived from the weight difference before and after treatment (Chai \& Udén P 1998). Acid detergent fibre and acid detergent lignin contents were determined according to Robertson \& Van Soest (1981), using the permanganate method, as performed by the Department of Soil and Environment, Swedish University of Agricultural Sciences (Skara, Sweden). Neutral detergent fibre represents the total cell wall content of hemicellulose, cellulose and lignin, while acid detergent fibre is a subcomponent of the neutral detergent fibre, containing cellulose and lignin. The lignin content of the feed is given as acid detergent lignin. 


\section{Statistical analyses}

The statistical analyses were performed using $\mathrm{R}$ 3.4.1 for Windows (R Development Core Team 2017). We analysed the variation in methane emission per day, and per day per kg, mass-specific $V_{\mathrm{O} 2}$ (resting oxygen uptake rate), and the proportion of GEI lost as methane, using identically structured linear mixed models fitted with the lmer function from the lme 4 package (Bates et al. 2015). Specifically, we considered three alternative models with either feed type, feed type and date, or the full factorial term (i.e., feed type $x$ date), as covariates. All models also included a random intercept for "“subject id"' to account for repeated sampling, which improved model fit in all cases (mean \pm SE $\triangle$ AIC: $4.9 \pm 1.5$ ). We compared the AIC for all original models (fitted with Maximum Likelihood), and selected the model with the lowest AIC as our final model. When $\triangle$ AIC for alternative models was $<2$, we selected the most parsimonious model as final. We then refitted this model with Restricted Maximum Likelihood (Zuur et al. 2009), and calculated degrees of freedom using the Satterthwaite approximation (lmerTest package; Kuznetsova et al. 2017). Diagnostics plots confirmed that the model of percentage of gross energy intake lost as methane performed better with an untransformed response variable than with logit- or arcsine square root-transformed values (the final model structure did not differ depending on different transformations). Body mass variation between feeding treatments was compared in a mixed-effects model (fitted with lmer from the lme4 package) with body mass as the dependent variable, feed type as a fixed factor, and subject ID as a random factor. Apart from results on feed composition and energy content, which are presented as means $\pm \mathrm{SD}$, data in tables and text are least square means $\pm \mathrm{SE}$ (estimated using the lsmeans package; Lenth 2016), and all significances are two-tailed.

\section{Results}

The concentrate feed produced for reindeer (Felleskjøpet, Norway) contained high concentrations of crude protein, fat, ash, water-soluble carbohydrates, starch and acid detergent lignin compared to the lichens (mainly Cladonia stellaris) diet (Table 1). The lichen diet consisted mostly of carbohydrates extracted in the neutral detergent fibre fraction of the chemical analysis $(82.2 \pm 1.13 \%$ of DM), in addition to starch comprising 6.0\% DM (Table 1).

The average body mass and DM feed intake was $61 \pm 1.34 \mathrm{~kg}(n=5)$ and $0.434 \pm 0.003 \mathrm{~kg}$ on the concentrate feed, and $53.4 \pm 1.34 \mathrm{~kg}$ and $0.450 \pm 0.053 \mathrm{~kg}$ on the lichen diet (Table 2). The reindeer had a similar intake pattern for both diets, and finished their meal within the first hour after feeding either pellets or lichens.

Table 2. Parameter estimates, degrees of freedom, and $F$ and $p$ values for final models. For interactions, estimates represent the slope of the relationship between the dependent variable and the covariate for each of the factor levels. For main effects, estimates are the least squares means as predicted for the final model. For main effects in interaction models, estimates are the least squares means disregarding any other factors/ covariates in the model. Degrees of freedom were estimated using the Satterthwaite approximation.

\begin{tabular}{|c|c|c|c|c|}
\hline Parameter & Estimate (SE) & df & $F$ & $p$ \\
\hline \multicolumn{5}{|c|}{ Total methane emission $\left(\mathrm{g} \mathrm{d}^{-1}\right)$} \\
\hline Feed (Pellets | Lichens) & & $1,13.54$ & 16.93 & 0.001 \\
\hline Feed $=$ Pellets & $11.173(0.542)$ & & & \\
\hline Feed $=$ Lichens & $7.498(0.545)$ & & & \\
\hline Julian date ( 1 = 1 January) & $-0.049(0.005)$ & $1,14.89$ & 4.60 & 0.049 \\
\hline Feed $\times \times$ Julian date & & $1,11.97$ & 8.94 & 0.011 \\
\hline Feed $=$ Pellets & $0.004(0.026)$ & & & \\
\hline Feed $=$ Lichens & $0.111(0.037)$ & & & \\
\hline \multicolumn{5}{|c|}{ Specific methane emission $\left(\mathrm{g} \mathrm{kg}^{-1} \mathrm{~d}^{-1}\right)$} \\
\hline Feed (Pellets | Lichens) & & $1,14.37$ & 26.15 & $<0.001$ \\
\hline Feed $=$ Pellets & $0.1834(0.0095)$ & & & \\
\hline Feed $=$ Lichens & $0.1405(0.0097)$ & & & \\
\hline Julian date ( 1 = 1 January) & $-0.0006(0.0001)$ & $1,14.73$ & 10.70 & 0.005 \\
\hline Feed $\times \times$ Julian date & & $1,12.58$ & 16.65 & 0.001 \\
\hline Feed $=$ Pellets & $0.0002(0.0005)$ & & & \\
\hline Feed $=$ Lichens & $0.0029(0.0007)$ & & & \\
\hline \multicolumn{5}{|l|}{ Specific $V_{\mathrm{O} 2}\left(\mathrm{l}_{\mathrm{O} 2} \mathrm{~kg}^{-1} \mathrm{~d}^{-1}\right)$} \\
\hline Feed (Pellets | Lichens) & & $1,13.23$ & 35.08 & $<0.001$ \\
\hline Feed $=$ Pellets & $7.917(0.205)$ & & & \\
\hline Feed $=$ Lichens & $6.790(0.210)$ & & & \\
\hline \multicolumn{5}{|c|}{ Proportion gross energy lost as methane $\left(\mathrm{E}_{\mathrm{CH} 4}\right)$} \\
\hline Feed (Pellets | Lichens) & & $1,12.94$ & 107.12 & $<0.001$ \\
\hline Feed $=$ Pellets & $0.0760(0.0037)$ & & & \\
\hline Feed $=$ Lichens & $0.0523(0.0037)$ & & & \\
\hline \multicolumn{5}{|l|}{ Body mass $(\mathrm{kg})$} \\
\hline Feed (Pellets | Lichens) & & $1,14.00$ & 99.32 & $<0.001$ \\
\hline Feed $=$ Pellets & $60.980(1.341)$ & & & \\
\hline Feed $=$ Lichens & $53.325(1.341)$ & & & \\
\hline
\end{tabular}




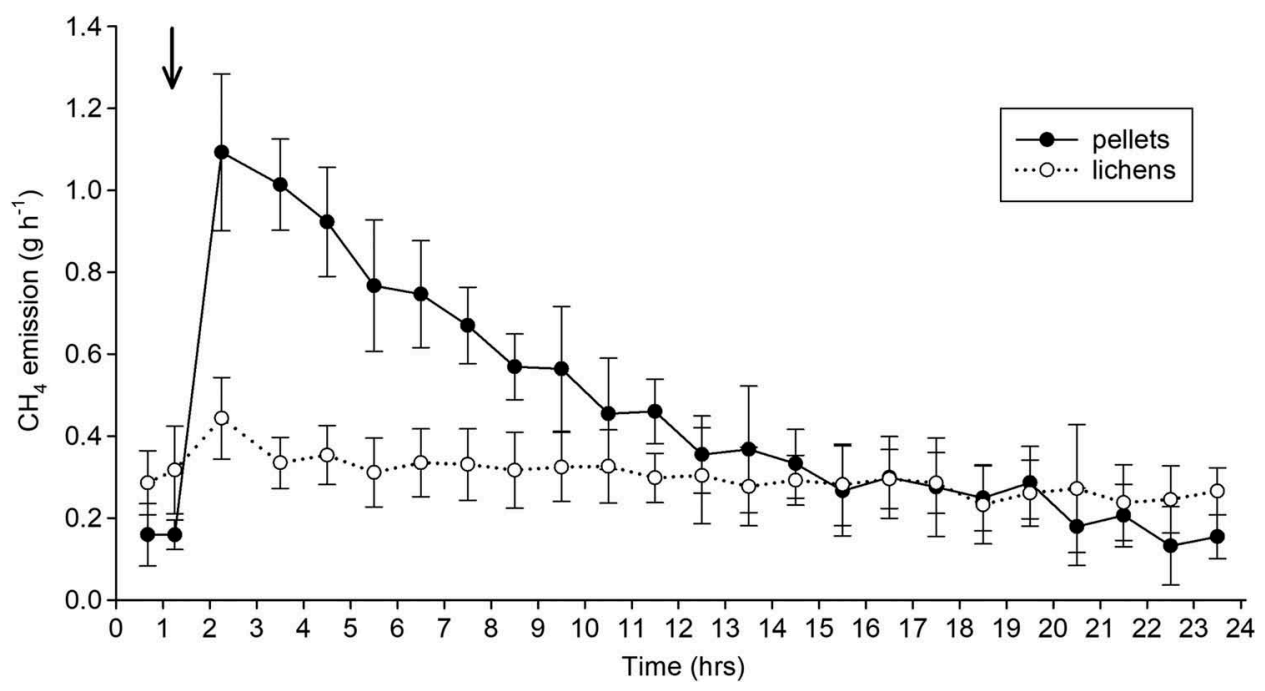

Figure 1. Mean hourly methane emission rates $\left( \pm\right.$ S.D.) $\left(g_{\mathrm{CH} 4} \cdot h^{-1}\right)$ by reindeer $(n=5)$ during $24 h$ (data for the last hour extrapolated). The reindeer were fed $2 \mathrm{~h}$ into the experiment (arrow), with a concentrate feed (solid line/closed symbols) or a mixture of lichens (dashed line/open symbols).

Methane emission from reindeer increased in response to intake of the concentrate feed, and was elevated for the following 8-12 $\mathrm{h}$, while methane emission from reindeer fed lichens did not increase above baseline levels in response to feeding (Fig. 1). The mean methane emission from reindeer fed lichens was $7.5 \pm 0.54 \mathrm{~g} \cdot$ day $^{-1}$, compared to $11.2 \pm 0.54 \mathrm{~g} \cdot$ day $^{-1}$ from reindeer fed the same DM amount of pellets (Table 2). This difference was significant $(p=0.001)$. There was also a difference $(p<0.001)$ between the two feeds when methane loss was expressed in terms of energy loss in \% of GEI ( $\left.\mathrm{E}_{\mathrm{CH} 4} ; \%\right)$ : lichens: $5.2 \pm 0.37 \%$; pellets: $7.6 \pm 0.37 \%$. Calculated as methane yield, the reindeer fed pellet emitted $25.7 \pm 1.24 \mathrm{~g} / \mathrm{kg}$ DMI, while the reindeer fed lichens emitted $16.6 \pm 1.21 \mathrm{~g} / \mathrm{kg}$ DMI. There was a clear interaction effect $(F=8.94$, $p=0.011$ ) between feed and (Julian) date while the animals were fed lichens (Table 2).

The oxygen concentration of the outlet air never dropped below $20.48 \%$, showing that the respiration chamber was well ventilated at all times. The mean mass-specific oxygen uptake rate $\left(V_{\mathrm{O}_{2}}\right)$ was significantly higher $(F=35.08, p<0.001)$ when the reindeer were fed pellets $\left(7.92 \pm 0.20 \mathrm{l}_{\mathrm{O} 2} \cdot \mathrm{kg}^{-1} \cdot\right.$ day $\left.^{-1}\right)$ than when fed lichens $\left(6.8 \pm 0.21 \mathrm{l}_{\mathrm{O} 2} \cdot \mathrm{kg}^{-1} \cdot\right.$ day $\left.^{-1}\right)$.

\section{Discussion}

This study has shown that reindeer fed lichens emitted significantly less methane compared to when fed concentrate pellets in equal (DM mass) or equi-caloric amounts (Table 2), even when the lesser body mass of lichens-fed animals was taken into account (methane emission was $0.1834 \mathrm{~g} /$ day $/ \mathrm{kg}$ body mass on a pellets diet versus $0.1405 \mathrm{~g} / \mathrm{day} / \mathrm{kg}$ body mass on a lichen $\operatorname{diet}[F=26.15, p<0.001])$. Several factors may have caused this difference.

Secondary phenolic compounds in the diet, energy intake and relative proportions of volatile fatty acids in the rumen all have the potential to influence methane production in ruminants (Lawler 2001). More than 600 different secondary compounds have been reported in lichens, including a large amount of the antibiotic usnic acid (Sundset et al. 2010). Such plant secondary metabolites may have a direct toxic effect on the rumen methanogens or their symbiotic protozoa and thereby contribute to reduce methane emission (Bodas et al. 2012). A mixed lichen diet dominated by Cladonia stellaris, such as the one fed to our reindeer in this present study may contain as much as $9.1 \mathrm{mg} \mathrm{x}$ $\mathrm{g}^{-1}$ DM of the secondary compound usnic acid (Sundset et al. 2010). Microbial fermentation in the reindeer rumen has been shown to allow detoxification of dietary secondary compounds (Sundset et al. 2008; Sundset et al. 2010), but the mechanistic effects of lichens on methanogens and thereby on emission of methane from reindeer remain unknown. A recent study by Salgado-Flores et al. (2016), examining the effect of lichens consumption and the consumption of a concentrate feed on the rumen and caecum microbiotas in reindeer, showed that the overall density of methanogens was independent of diet. The archaeal and bacterial diversity differed significantly in both compartments, depending on diet (Salgado-Flores et al. 2016). These altered methanogen and bacterial profiles may explain the significantly lower methane emission from reindeer fed lichens compared to when fed concentrate pellets. We know from other ruminants that methanogens belonging to the genus Methanobrevibacter are predominant in the rumen (King et al. 2011). Methanobrevibacter-related sequences are distributed between two major clades, 
the SGMT clade and the RO clade (King et al. 2011; StPierre \& Wright 2012). Sequences within a host tend to group phylogenetically either within the SGMT or the RO clade, so that hosts with a large representation of the SGMT group, typically have lower representation of the RO group and vice versa. Salgado-Flores et al. (2016) found a decreased ratio between methanogens of the SGMT clade and methanogens of the RO clade with the ingestion of lichens in reindeer, suggesting an increased proportion of RO-methanogens associated to lower $\mathrm{CH}_{4}$ output as discussed in other ruminants. Furthermore, Salgado-Flores et al. (2016) demonstrated a lower abundance of predicted genes associated with $\mathrm{CH}_{4}$ metabolism in lichen-fed reindeer, supporting our findings that methane emissions are reduced in lichen-fed reindeer.

Both nitrogenous compounds and carbohydrates are needed to produce microbial cells, volatile fatty acids and methane (Wolin \& Miller 1988; Ørskov 1992; Moss et al. 2000). The different proportions of these in the lichens and pellets (Table 1) could therefore also explain the observed difference in methane emission. For example, an increased intake of starch often decreases methane emissions (Johnson \& Johnson 1995). In the present study, lower methane emissions were observed in reindeer fed lichens compared to concentrate pellets. Lichens consist of many different carbohydrate fractions, with large differences in composition between the different species eaten by reindeer (Svihus \& Holand 2000). Lichenin, also known as lichenan or moss starch, is a chemically complex glucan, occurring in certain species of lichens. Some lichens are high in lichenan, e.g., Cetraria islandica (27\% of DM) and $C$. nivalis ( $18 \%$ of DM). These were both part of our lichen diet in addition to larger amounts of Cladonia stellaris, which contains less lichenan (0.1\% of DM; Svihus \& Holand 2000). Our chemical studies (Table 1) showed that the lichens mix used in our study contained $6.0 \%$ DM starch.

On the other hand, fermentation of proteins typically results in less volatile fatty acids compared to fermentation of carbohydrates (Sveinbjörnsson et al. 2006). Less methane would therefore be expected to be produced on the more protein-rich pellets diet $(12.7 \%$ of DM; Table 1). This was not the case in the present study, possibly because of the much lower protein content in lichens $(<2.6 \%$ of DM $)$, which may have been too low to sustain sufficient microbial growth, thereby causing lower fermentation and low methane production. Lichen's protein content is too low to allow reindeer to maintain a net balance of protein, so the animal has to mobilize body proteins and therefore loses body mass, as normally seen in late spring in reindeer (McEwan \& Whitehead 1970), compared to when they were fed pellets in January/March. Hence, reindeer require a combination of lichens and vascular plants to maintain a stable body mass in winter. Wintergreen parts of graminoids contain $10 \%$ protein, approximately the same amount as concentrate feed (Storeheier et al. 2002). This additional nitrogen source on natural pastures may prevent mobilization of muscle protein, but might also affect the methane emission from reindeer differently from when measured here on the lichen diet.

The results of the present study can, of course, not be directly extrapolated to free-ranging animals on natural pastures, because of the different feeding conditions, diet and intake. For example, studies of other ruminants have shown that methane emission increases with increasing intake (Blaxter \& Clapperton 1965). Great variability in methane emission across successive days has been noticed in multiday trials and is to a great extent related to variable intake of food (e.g., Jonker et al. 2016). In the present study we did not record methane emission during consecutive days, but rather for two individual days per animal per diet. In contrast to many other studies, we standardized the level of intake to a given amount of food so that all of it was eaten in one batch at the beginning of each experiment. This removed the factor of DMI, which is a main determinant of total methane production in ruminants (Ramin \& Huhtanen 2013).

Methane energy losses relative to GEI may vary between 2 and $15 \%$ in other domesticated ruminants, but mainly range between 5 and $6.5 \%$ (Blaxter \& Clapperton 1965; Holter \& Young 1992; Johnson \& Ward 1996). Our data from reindeer were within (for lichens) or slightly above (for concentrate feed) this range. The variable methane emission from different ruminants may, of course, be related to species and body size, but also to dietary compositions, differences in gut anatomy and differences in their gut microbiomes (Blaxter \& Clapperton 1965).

In order to compare methane emission from reindeer with those from other herbivores further, we have also performed a pilot study with an identical experimental set-up and design, using Norwegian sheep (Ovis aries). Our study of sheep also indicated a depression in mean methane emission in relation to GEI, from sheep $(n=2)$ fed lichens $(2.8 \pm 1.0 \%)$ compared to sheep eating the concentrate reindeer feed $(5.0 \pm 0.9 \%)$ (Nilsen 2013). In both reindeer and sheep, the methane emission rate increased markedly after intake of the concentrate feed, while intake of lichens did not cause any detectable change to the basal emission rate.

Comparing $\mathrm{CH}_{4}$ emission between different diets and even more so between different studies is challenging because data on methane emission are presented using different units. We have presented our data in $\mathrm{g} \mathrm{CH} \mathrm{CH}_{4}$ /day and $\mathrm{CH}_{4}$ in \% of GEI $\left(\mathrm{E}_{\mathrm{CH} 4}\right)$ (Table 2). $\mathrm{E}_{\mathrm{CH} 4}$ relates methane emission to the energy intake and hence to the chemistry (energy 
contents) of the feed, and to the amount of feed eaten, but does not take into account, e.g., differences in the in vivo DM digestibility of the different feeds. When the digestibility of energy increases, energy lost as methane also increases (Blaxter \& Clapperton 1965). We know that the reindeer rumen microflora has evolved to degrade/detoxify lichen secondary compounds, and that reindeer are highly adapted to utilize lichens as a substrate for nutrients (Sundset et al. 2008; Sundset et al. 2010; Glad et al. 2014). In the present study, we used a lichen diet dominated by Cladonia stellaris but also containing small amounts of other lichen species included in the winter diet of reindeer. Storeheier et al. (2002) showed that the chemical composition and the in vitro digestibility of lichens eaten by reindeer varies considerably. However, in vivo digestibility of mixed lichens, consisting primarily of C. stellaris similar to our lichen diet, has been found to be high in reindeer $(69-81 \%$ DM digestibility) (Jacobsen \& Skjenneberg 1975, 1979; Øksendal 1994). Although we do not know the DM digestibility of the concentrate feed presently used, we do know from previous studies that the in vitro DM digestibility of RF-80 (a concentrate reindeer feed from the same company-Felleskjøpetresembling the reindeer feed used in our study) was 60.7\% (Storeheier et al. 2002). Hence, digestibility studies of lichens in reindeer show that the utilization is high (69-81\%), possibly even higher than that of the concentrate diet. Assuming a higher digestibility of lichens than that of pellets, reindeer need to eat less lichens than pellets to gain the same amount of energy and methane emission would be even higher on pellets compared to lichens than if only $\mathrm{E}_{\mathrm{CH} 4}$ values are compared between the diets (i.e., 58\% higher instead of ca. $50 \%$ higher, as we now report). A higher content of starch in the concentrate feed compared to the lichen diet (Table 1) may also in part explain the significantly higher output of methane by our pellet-fed animals (Table 2).

When the residence time in the rumen decreases with the increasing passage rate, the time available for microbial fermentation decreases and so does methane production. Rapid passage rate also favours propionate production (Moss et al. 2000). Since the rumen turn-over time in reindeer fed lichens is long (23-69 h according to Aagnes \& Mathiesen 1994), the passage time does not seem to explain the low methane production in reindeer fed lichens. Furthermore, Johnson et al. (1996) found that pelleting of forages decreases the methane production, as a result of an increase in passage time (Le-Liboux \& Peyraud 1999). However, these effects are not apparent when food intake is restricted, as it was in our experiments.

In conclusion, methane emission from reindeer was lower when fed a lichen diet compared to a diet of pellets feed normally used for supplementary feeding. This may be due to the low nitrogen content or the antimicrobial components of the lichens. Supplementary feeding has increased in Saami reindeer husbandry to ameliorate difficult winter condition, which is crucial for reindeer survival and production (Tyler et al. 2007). This study indicates that reindeer emit less methane when eating lichens instead of concentrate feed.

\section{Acknowledgements}

We are grateful to the staff of animal caretakers, Hans Lian, Hans Arne Solvang and John Ness, for their help in relation to the experiments. We thank post-doctoral fellow Andreas Nord for help with the statistics, Prof. OddMagne Harstad for helpful advice and constructive discussions and Lorenzo Ragazzi for technical assistance in connection with the experiments.

\section{Disclosure statement}

No potential conflict of interest was reported by the authors.

\section{Funding}

This study is linked to the framework of the International Polar Year as part of the consortium project \#399 EALAT: Climate Change and Reindeer Husbandry. Funding was provided by the Reindeer Husbandry Research Fund. The publication charges for this article have been funded by a grant from the UiT publication fund.

\section{Ethics statement}

Reindeer (Rangifer $t$. tarandus) are not an endangered or a protected species, and no specific permission was required to buy and transport the animals to UiT. The transport of the animals took $30 \mathrm{~min}$. All animal experiments were conducted after arrival to UiT, in the approved animal research facilities of the Department of Arctic and Marine Biology (approved by the Norwegian Food Safety Authority, approval no. 089). All procedures were approved by the Norwegian Animal Research Authority (permit nos. 3524 and 4003), and the ethics guidelines for research developed by the International Centre for Reindeer Husbandry were implemented.

\section{References}

Aagnes T.H. \& Mathiesen S.D. 1994. Food and snow intake, body mass and rumen function in reindeer fed lichen and subsequently starved for 4 days. Rangifer 14, 33-37.

Bajzelj B., Richards K.S., Allwood J.M., Smith P., Dennis J. S., Curmi E. \& Gilligan C.A. 2014. Importance of fooddemand management for climate mitigation. Nature Climate Change 4, 924-929.

Bates D., Maechler M., Bolker B. \& Walker S. 2015. Fitting linear mixed-effects models using lme4. Journal of Statistical Software 67, 1-48. 
Blaxter K.L. \& Clapperton J.L. 1965. Prediction of the amount of methane produced by ruminants. British Journal of Nutrition 19, 511-522.

Bodas R., Prieto N., García-González R., Andrés S., Giráldez F.J. \& López S. 2012. Manipulation of rumen fermentation and methane production with plant secondary metabolites. Journal of Animal Feed Science and Technology 176, 78-93.

Boehringer Mannheim. 1984. Methods of enzymatic food analysis using test combinations. Methods for food analysis. Mannheim, Germany: Boehringer Mannheim $\mathrm{GmbH}$.

Boertje R.D. 1984. Seasonal diets of the Deali caribou (Rangifer tarandus granti) herd, Alaska (USA). Arctic 37, 161-165.

Brouwer E. 1965. Report of sub-committee on constants and factors. In K.L. Blaxter (ed.): Proceedings of the $3 r d$ Symposium on Energy Metabolism. Pp. 441-443. London: Academic Press.

Chai W.H. \& Udén P. 1998. An alternative oven method combined with different detergent strengths in the analysis of neutral detergent fiber. Journal of Animinal Feed Science and Technology 74, 281-288.

Degteva A., Oskal A., Mathiesen S.D., Burgess P., Aslaksen I., Johnsen K., Magga A.-M., van Rooij W., Brattland C., Corell R., Dubovtsev A., Garnåsjordet P.A., Holmberg A., Klokov K., Maynard N.G., Nellemann C., Niillas B., Partapuoli P.J., Pogodaev M., Reinert E., Sandström P., Slepushkin I., Smuk I.A., Steffanson J., Strogalschikova Z., Tyskarev A. \& Westerveld L. 2017. Indigenous peoples' perspectives. In: AMAP 2017. Adaptation actions for a changing Arctic: perspectives from the Barents area. Pp. 167-194. Oslo: Arctic Monitoring and Assessment Programme.

Denman S.E., Tomkins N.W. \& McSweeney C.S. 2007. Quantification and diversity analysis of ruminal methanogenic populations in response to the antimethanogenis compound bromochloromethane. FEMS Microbiology Ecology 62, 313-322.

Eckard R.J., Grainger C. \& de Klein C.A.M. 2010. Options for the abatement of methane and nitrous oxide from ruminant production: a review. Livestock Science 130, 47-56.

Evans P.N., Hinds L.A., Sly L.I., McSweeney C.S., Morrison M. \& Wright A.-D.G. 2009. Community composition and density of methanogens in the foregut of the tammar wallaby (Macropus eugenii). Applied and Environmental Microbiology 75, 2598-2602.

Gaare E. \& Skogland T. 1975. Wild reindeer food habits and range use at Hardangervidda. In F.E. Wielgolaski (ed.): Ecological studies, analysis and synthesis. Fennoscandian tundra ecosystem. Pp. 195-205. Berlin: Springer.

Glad T., Barboza P., Mackie R.I., Wright A.-D.G., Brusetti L., Mathiesen S.D. \& Sundset M.A. 2014. Dietary supplementation of usnic acid, an antimicrobial compound in lichens, does not affect rumen bacterial diversity or density in reindeer. Current Microbiology 68, 724-728.

Gotaas G. \& Tyler N.J.C. 1994. Methane production and the doubly labelled water method in reindeer (Rangifer tarandus tarandus). Proceedings of the Society of Nutrition Physiology 3, 181.

Holleman D.F. \& Luick J.R. 1977. Lichens species preference by reindeer. Canadian Journal of Zoology 55, 1368-1369.

Holter J.B. \& Young A.J. 1992. Methane production in dry and lactating dairy cows. Journal of Dairy Science 75, 2165-2175.
Hook S.E., Northwood K.S., Wright A.-D.G. \& McBride B. W. 2009. Long-term monensin supplementation does not significantly affect the quantity or diversity of methanogens in the rumen of the lactating dairy cow. Applied and Environmental Microbiology 75, 374-380.

Inga B. 2007. Reindeer (Rangifer tarandus tarandus) feeding on lichens and mushrooms: traditional ecological knowledge among reindeer-herding Sami in northern Sweden. Rangifer 27, 93-106.

Ingolfsdottir K. 2002. Usnic acid. Phytochemistry 61, 729-736. Jacobsen E. \& Skjenneberg S. 1975. Some results from feeding experiments with reindeer. In J.R. Luick et al. (eds.): Proceedings of the First International Reindeer/Caribou Symposium. Pp. 95-107. Fairbanks: University of Alaska.

Jacobsen E. \& Skjenneberg S. 1979. Experiments with different diets fed to reindeer. Scientific Reports. Agricultural College of Norway 58, 1-11.

Johnson D.E. \& Ward G.M. 1996. Estimates of animal methane emissions. Environmental Monitoring and Assessment 42, 133-141.

Johnson K.A. \& Johnson D.E. 1995. Methane emissions from cattle. Journal of Animal Science 73, 2483-2492.

Jonker A., Molano G., Koolaard J. \& Muetzel S. 2016. Methane emissions from lactating and non-lactating dairy cows and growing cattle fed fresh pasture. Animal Production Science 57, 643-648.

Josefsen T.D. \& Sundset M.A. 2014. Fôring og fôringsbetingende sjukdommer hos rein. (Feeding and feed-related diseases among reindeer.) Norsk Veterinortidsskrift 2, 163-171.

King E.E., Smith R.P., St-Pierre B. \& Wright A.-D.G. 2011. Differences in the rumen methanogen populations of lactating Jersey and Holstein dairy cows under the same diet regiment. Applied and Environmental Microbiology 77, 5682-5687.

Kriss M. 1930. Quantitative relations of the dry matter of the food consumed, the heat production, the gaseous outgo, and the insensible loss in body weight of cattle. Journal of Agricultural Research 40, 283-295.

Kuznetsova A., Bruun P. \& Bojesen Christensen R.H. 2017. lmerTest: tests in linear mixed effects models. R Package Version 2.0-32. https://rdrr.io/github/alku86/lmerTest/.

Larsen T.S., Nilsson N.Ö. \& Blix A.S. 1985. Seasonal changes in lipogenesis and lipolysis in isolated adipocytes from Svalbard and Norwegian reindeer. Acta Physiologica Scandinavia 123, 97-104.

Lawler J.P. 2001. Heat increment and methane production by muskoxen fed browse. $\mathrm{PhD}$ thesis, University of Alaska Fairbanks.

Le-Liboux S. \& Peyraud J.L. 1999. Effect of forage particle size and feeding frequency on fermentation patterns and sites and extent of digestion in dairy cows fed mixed diets. Animal Feed Science and Technology 76, 297-319.

Lenth R.V. 2016. Least-squares means: the R package lsmeans. Journal of Statistical Software 69, 1-33.

Martin C., Morgavi D.P. \& Doreau M. 2010. Methane mitigation in ruminants: from microbe to the farm scale. Animal : an International Journal of Animal Bioscience 4, 351-365.

McEwan E.H. \& Whitehead P.E. 1970. Seasonal changes in the energy and nitrogen intake in reindeer and caribou. Canandian Journal of Zoology 48, 905-913.

Moe P.W. \& Tyrrell H.F. 1979. Methane production in dairy cows. Journal of Dairy Science 62, 1583-1586.

Moss A.R., Jouany J.P. \& Newbold J. 2000. Methane production by ruminants: its contribution to global warming. Annales De Zootechnie 49, 231-253. 
Nash T.H. III 1996. Lichen biology. Cambridge: Cambridge University Press.

Nilsen M. 2013. Ernoringsbasert matproduksjon hos sau. (Nutrition-based food production in sheep.) Master's thesis, Department of Biology, UiT-University of Tromsø: Norway.

Nilssen K.J., Sundfjord J.A. \& Blix A.S. 1984. Regulation and metabolic rate in Svalbard and Norwegian reindeer. American Journal of Physiology, Regulatory Integrative Comparative Physiology 247, R837-R841.

Norberg H., Maijala V. \& Nieminen M. 2001. Palatability and nutrient composition of plants, fungi and lichens foraged by reindeer. Programme and Abstracts 11th Nordic Conference on Reindeer Research, Kaamanen 18-20 June 2001. Rangifer Report 5, 66-67.

Ørskov E.R. 1992. Protein nutrition in ruminants. London: Academic Press Limited.

Øksendal H. 1994. Lav og rundballeensilert engsvingel som krisefór til reinkalvar, innverknad på mage-tarm anatomien og evnen til cellulose gjoring. (Lichen and baled meadow fescue silage as an emergency food for reindeer calves; influence on the gastrointestinal anatomy and the ability to ferment cellulose.) Tromsø: Norwegian College of Agriculture/University of Norway.

R Development Core Team. 2017. R: a language and environment for statistical computing. Vienna: R Foundation for Statistical Computing.

Ramin M. \& Huhtanen P. 2013. Development of equations for predicting methane emissions from ruminants. Journal of Dairy Science 96, 2476-2493.

Robertson J.B. \& Van Soest P.J. 1981. The detergent system of analysis and its application to human foods. In W.P.T. James et al. (ed.): The analysis of dietary fiber in food. Pp. 123-158. New York: Marcel Decker.

Salgado-Flores A., Hagen L.H., Ishaq S.L., Zamanzadeh M., Wright A.-D.G., Pope P.B. \& Sundset M.A. 2016. Rumen and cecum microbiomes in reindeer (Rangifer tarandus tarandus) are changed in response to a lichen diet and may affect enteric methane emissions. PLoS One 11, e0155213, doi: 10.1371/journal.pone.0155213.

Scotter G.W. 1967. The winter diet of barren-ground caribou in northern Canada. Field Naturalist 81, 33-39.

Steen E. 1968. Some aspects of the nutrition of semi-domestic reindeer. In M.A. Crawford (ed.): Comparative nutrition of wild animals. Symposia of the Zoological Society of London. Vol. 21. Pp. 117-128. London: Academic Press.

Storeheier P.V., Mathiesen S.D., Tyler N.J.C. \& Olsen M.A. 2002. Nutritive value of terricolous lichen for reindeer in winter. Lichenologist 34, 247-257.

Storeheier P.V., Mathiesen S.D., Tyler N.J.C., Schjelderup I. \& Olsen M.A. 2002. Utilization of nitrogen- and mineral-rich vascular forage plants by reindeer in winter. Journal of Agricultural Science 139, 151-160.

St-Pierre B. \& Wright A.-D.G. 2012. Molecular analysis of methanogenic archaea in the forestomach of the alpaca (Vicugna pacos). BMC Microbiology 12(1), article no. 1, doi: 10.1186/1471-2180-12-1.
Sundset M.A., Barboza P.S., Green T.K., Folkow L.P., Blix A.S. \& Mathiesen S.D. 2010. Microbial degradation of usnic acid in the reindeer rumen. Naturwissenschaften 97, 273-278.

Sundset M.A., Edward J.E., Cheng Y.F., Senosiain R.S., Fraile M.N., Northwood K.S., Præsteng K.E., Glad T., Mathiesen S.D. \& Wright A.-D.G. 2009a. Molecular diversity of the rumen microbiome of Norwegian reindeer on natural summer pasture. Microbial Ecology 57, 335-348.

Sundset M.A., Edward J.E., Cheng Y.F., Senosiain R.S., Fraile M.N., Northwood K.S., Præsteng K.E., Glad T., Mathiesen S.D. \& Wright A.-D.G. 2009b. Rumen microbial diversity in Svalbard reindeer with particular emphasis on methanogenic archaea. FEMS Microbiology Ecology 70, 553-562.

Sundset M.A., Kohn A., Mathiesen S.D. \& Præsteng K.E. 2008. Eubacterium rangiferina, a novel usnic acid-resistant bacterium from the reindeer rumen. Die Naturwissenschaften 95, 741-749.

Sundset M.A., Præsteng K.E., Cann I.K.O., Mathiesen S.D. \& Mackie R.I. 2007. Novel rumen bacterial diversity in two geographically separated sub-species of reindeer. Microbial Ecology 54, 424-438.

Suzuki T., McCrabb G.J., Nishida T., Indramanee S. \& Kurihara M. 2007. Construction and operation of ventilated hood-type respiration calorimeters for in vivo measurement of methane production and energy partition in ruminants. In H.P.S. Makkar \& P.E. Vercoe (eds.): Measuring methane production from ruminants. Pp. 125-135. Dordrecht: Springer.

Sveinbjörnsson J., Hutanen P. \& Udén P. 2006. The nordic dairy model karoline- development of VFA submodel. In E. Kebreab et al. (ed.): Nutrient digestion and utilisation in farm animals: modelling approaches. Pp. 1-14. Wallington, UK: CAB International.

Svihus B. \& Holand Ø. 2000. Lichen polysaccharides and their relation to reindeer/caribou nutrition. Journal of Range Management 53, 642-648.

Turi J.M. 2002. The world reindeer livelihood current situation, threats and possibilities. In S. Kankaanpää et al. (ed.): Northern timberline forests: environmental and socio-economic issues and concerns. Finnish Forest Research Institute Research Paper. Vol. 862. Pp. 70-75. Helsinki: Finnish Forest Research Institute.

Tyler N.J.C., Turi J.M., Sundset M.A., Strøm Bull K., Sara M.N., Reindert E., Oskal N., Nellemann C., McCarthy J. J., Mathiesen S.D., Martello M.L., Magga O.H., Hovelsrud G.K., Hanssen-Bauer I., Eira N.I., Eira I.M. G. \& Corell R.W. 2007. Saami reindeer pastoralism under climate change: applying a generalized framework for vulnerability studies to a sub-Arctic social-ecological system. Global Environmental Change 17, 191-206.

Vaisala 2013. Humidity conversion formulas. Calculation formulas for humidity. Helsinki: Vaisala Oyj.

Wolin M.J. \& Miller T.L. 1988. Microbe-microbe interactions. In P.N. Hobson (ed.): The rumen microbial ecosystem. Essex: Elsevier.

Zuur A.F., Ieno E.N., Walker N.J., Saveliev A.A. \& Smith G. M. 2009. Mixed effects models and extensions in ecology with $R$. New York: Springer. 